\title{
Neo-liberal economic practices and population health: a cross-national analysis, 1980-2004
}

\author{
MELISSA TRACY \\ Doctoral student, Department of Epidemiology, School of Public Health, University of Michigan, USA \\ MARGARET E. KRUK \\ Assistant Professor of Health Management and Policy, School of Public Health, University of Michigan, USA \\ CHRISTINE HARPER \\ Research Assistant, Department of Epidemiology, School of Public Health, University of Michigan, USA \\ SANDRO GALEA* \\ Professor of Epidemiology, School of Public Health, Director, Center for Global Health, University of Michigan, \\ USA
}

\begin{abstract}
Although there has been substantial debate and research concerning the economic impact of neo-liberal practices, there is a paucity of research about the potential relation between neo-liberal economic practices and population health. We assessed the extent to which neo-liberal policies and practices are associated with population health at the national level. We collected data on 119 countries between 1980 and 2004. We measured neo-liberalism using the Fraser Institute's Economic Freedom of the World (EFW) Index, which gives an overall score as well as a score for each of five different aspects of neo-liberal economic practices: (1) size of government, (2) legal structure and security of property rights, (3) access to sound money, (4) freedom to exchange with foreigners and (5) regulation of credit, labor and business. Our measure of population health was under-five mortality. We controlled for potential mediators (income distribution, social capital and openness of political institutions) and confounders (female literacy, total population, rural population, fertility, gross domestic product per capita and time period). In longitudinal multivariable analyses, we found that the EFW index did not have an effect on child mortality but that two of its components: improved security of property rights and access to sound money were associated with lower under-five mortality $(p=0.017$ and $p=0.024$, respectively). When stratifying the countries by level of income, less regulation of credit, labor and business was associated with lower under-five mortality in high-income countries $(p=0.001)$. None of the EFW components were significantly associated with under-five mortality in low-income countries. This analysis suggests that the concept of 'neo-liberalism' is not a monolithic
\end{abstract}

\footnotetext{
*Correspondence to: Sandro Galea, Director of the Center for Global Health, Professor of Epidemiology, School of Public Health, 109 Observatory Street, Room 3663, Ann Arbor, MI 48109-2029, USA. Email: sgalea@umich.edu
} 
entity in its relation to health and that some 'neo-liberal' policies are consistent with improved population health. Further work is needed to corroborate or refute these findings.

\section{Introduction}

Neo-liberal thinking emphasizes individual choice in the marketplace combined with limited government involvement in the economy. As an economic theory, neo-liberalism was developed in the 1960 s by proponents such as Friedman (1962), becoming a dominant model in policy discussions during the 1970s and continuing to play an important role in informing political and economic discussion worldwide to this day. Essentially, neo-liberalism is a restoration of the laissez-faire and free trade theories of economics popularized in the 18th and 19th centuries by economists such as Smith (1991) and Ricardo (1996) adjusted to today's global economy. The core component of neo-liberal economic philosophy is that economic decisions are best left to individuals, who will allocate their resources in the most utilitarian manner for their own needs. Markets, as groupings of individuals, require only minimal interference from government, whose role should be limited to promoting an environment in which property rights are protected, contracts are respected and the money supply is stable (Morgens, 1976; Gwartney et al., 1999). Privatization is a core component of neo-liberal thought, as governments are viewed as inefficient economic players incapable of running large business enterprises (Shleifer, 1998). At the national level, neo-liberalism endorses the removal or reduction of market impediments such as tariffs, high marginal tax rates, ownership restrictions, and government transfers and subsidies. At the international level, it promotes trade as the best method to bring about economic development for less developed countries, and therefore opposes trade restrictions (Kreuger, 1998). As a school of thought, then, neo-liberalism encompasses three basic tenets: (1) non-intervention by government in the marketplace, (2) equal protection of property rights and contract enforcement under the law and (3) free trade.

Advocates of neo-liberalism argue that increased economic freedom is the most efficient and democratic manner through which to promote economic growth (Ayal and Karras, 1998; Cole, 2003). Neo-liberal thinking contends that economic freedom may improve political freedom and that, in conjunction with the benefits of increased trade, it lessens social ills in the long run (Friedman, 1962; Price et al., 1999). For example, one argument put forth by proponents of neo-liberalism is that increased levels of democracy coupled with freer trade may have equalizing effects on income distribution (Reuveny and Li, 2003). Democratic societies have more political participation by groups that may be underserved in less open societies, and these groups demand smaller income 
disparities. Also, trade should lessen income inequality through increased competition that lowers the cost of basic consumer goods (Birdsall, 1998).

Conversely, neo-liberalism's critics maintain that such policies primarily benefit the wealthy and deprive vulnerable population groups of social safety nets (Clark et al., 2005; Labra, 2002; Lynch, 2000). It has been argued that neoliberalism widens the income divide and weakens social cohesion, causing social safety nets to shrink to the detriment of at-risk populations (Wennemo, 1993; Cornia, 2003; Coburn, 2004; Wu and Perloff, 2006). Some research has demonstrated a link between increased government transfers (i.e. social welfare programs) and improved absolute and relative poverty measures; these programs would be reduced or eliminated in the neo-liberal ideal (Kenworthy, 1999; Labao and Hooks, 2003; Kunitz and Pesis-Katz, 2005).

\section{Neo-liberalism and population bealth}

While the debate about the economic impact of neo-liberal practices has been accompanied by substantial empiric research on the topic, less research has been carried out documenting the effect, if one exists, of neo-liberalism on population health. However, several theoretical models have been proposed to explain how neo-liberalism may affect health outcomes. David Coburn proposed a framework in which more neo-liberal practices increase income inequality and reduce social cohesion to the overall detriment of population health (Muntaner and Lynch, 1999; Coburn, 2000). Coburn argues that neo-liberalism is at least not averse to, and may encourage, socio-economic disparities because individuals are rewarded and punished by an indifferent market in relation to their inputs. Coburn cites a body of empirical work that has demonstrated the negative relation between particular components of neo-liberalism, especially as regards government transfers, and national income inequality. For example, relative poverty increases as the proportion of gross domestic product (GDP) spent by the government as social transfer payments decreases (Kenworthy, 1999). Another study, classifying countries by government methods for redistribution of resources, found a negative association between the degree to which a country follows the traditional welfare state pattern and its level of income inequality (Korpi and Palme, 1998). In addition, Coburn argues that neoliberalism's emphasis on the individual and his or her complete freedom to act within the market necessarily de-emphasizes the public or communal sphere, reducing social cohesion (Muntaner and Lynch, 1999; Coburn, 2000). Privatization of most public goods is a central component of neo-liberal thought; this process commodifies all aspects of human existence and creates a strict delineation between 'mine' and 'yours', eliminating anything which could be considered 'ours' (Nettleson and Burrows, 1998). Day-to-day life becomes a Hobbesian struggle for survival in an asocial environment. Therefore, Coburn and others have argued that in countries where neo-liberal political philosophies 
are dominant, greater income inequality and reduced social cohesion mediate a relation between neo-liberalism and adverse health outcomes (Coburn, 2000; Lynch, 2000; Tarlov, 2000).

Some researchers have disputed this emphasis on neo-liberalism as a determinant of health. Wilkinson (2000) for example, argues that the traditional welfare states were only marginally successful at income re-distribution in the first place and that such "anti"-neo-liberal devices as universal health care systems ultimately have little impact on health because socio-economic factors are more important determinants of individual and population health. Others, while in general agreement with Coburn, have questioned the relative contribution of neo-liberal practices to overall population health and have suggested that neo-liberalism is only one piece in the puzzle of social change which occurred in the 20th century, a time of dramatically improved population health (Hertzman, 2000; Lynch, 2000; Tarlov, 2000). Several authors have emphasized the need for empirical studies to test the theorized relationship between neo-liberalism and population health (Lynch, 2000; Tarlov, 2000).

Some authors have written regarding the implementation of neo-liberal reforms within a country and the effects of these policies on health measures. These analyses have typically reported anecdotal evidence of a negative association between neo-liberalism and health (Labra, 2002; Cupples, 2005). However, few empirical studies analyze the effect of neo-liberalism on health directly. Mehrtens (2004), examining recent data, found an association between certain components of neo-liberalism and higher infant mortality in 18 highincome countries. Navarro et al. (2006) observed a strong correlation between longer years of government by pro-redistributive parties, which would be antithetical to neo-liberal policies, and lower infant mortality. In contrast to these findings of potentially detrimental effects of neo-liberalism on population health, Grubel (1998) and Esposto and Zaleski (1999) found some evidence for a relation between higher levels of neo-liberalism and improved life expectancy. However, all of these analyses have focused on small or unspecified samples of countries, have looked at only cross-sectional associations, or have failed to include controls for other country-level characteristics that may be important confounders or in the pathway between neo-liberal practices and population health.

In this paper, informed by the theoretical rationales discussed above for neoliberalism's potential role in shaping population health, we present a crossnational evaluation of the relation between components of neo-liberalism and population health over time. We examined the relation between different aspects of neo-liberalism and under-five mortality across 119 countries between 1980 and 2004. We also examined the roles of income inequality, social capital and democratic institutions, which have been hypothesized to be potential mediators of the relation between neo-liberalism and population health (Muntaner and Lynch, 1999; Coburn, 2000; Shandra et al., 2004). 
Neo-liberal economic practices and population health 5

\section{Methods}

\section{Key dependent and independent variables}

\section{Population health}

We used a measure commonly employed in cross-national analyses to evaluate population health as our health indicator of interest (Rodgers, 1979; Wennemo, 1993; Shen and Williamson, 2001; Moore et al., 2006). Under-five (or child) mortality rate is "the probability that a newborn will die before reaching age five, if subject to current age-specific mortality rates", expressed as rate per 1000 live births (World Bank, 2005). This measure more accurately reflects current population health than other indicators, such as life expectancy, which may in fact measure the health of a population as it was years earlier (Coburn, 2004). Mortality data were obtained from the World Bank's World Development Indicators (WDI) database, which uses data from the United Nations and UNICEF (World Bank, 2005).

\section{Neo-liberalism}

We assessed each country's degree of neo-liberal economic policies and practices using scores from the Economic Freedom of the World: 2005 Annual Report published in association with the Fraser Institute (Gwartney and Lawson, 2005). The Economic Freedom of the World (EFW) index has been created for 123 countries, many with data from 1970 to the present. The overall index is the average of its five component parts, each measured on a scale of 0 to 10 with a higher number signifying more neo-liberal tendencies. These components comprise five areas central to neo-liberal precepts: (1) size of government, (2) legal structure and security of property rights, (3) access to sound money, (4) freedom to exchange with foreigners and (5) regulation of credit, labor and business. Each component is discussed in detail further. Hong Kong and Singapore had the highest scores on the EFW index in 2003 (8.7 and 8.5, respectively), whereas Zimbabwe (3.3) and Myanmar (3.1) scored the lowest. Country rankings differ across each of the five components; examples of countries with high and low scores, in 2003, on each component are provided below (Gwartney and Lawson, 2005).

(1) The size of government component of the EFW index measures total government spending and the value of government transfers and subsidies as a proportion of total national spending, the value of government businesses compared to total investment, and maximum tax rates, both individual and corporate. Countries with less government involvement in economic life will score higher on this component than countries with extensive social welfare programs, since such programs are antithetical to neo-liberalism. Ecuador (9.0) had the highest score for the size of government component in 2003, while Sweden (3.0) had the lowest. 
(2) The legal structure and security of property rights component examines whether an independent judiciary exists and if it is impartial, whether intellectual property rights are recognized, and whether the country has a civiliancontrolled military. Denmark (9.5) had the highest score on this component, while Rwanda (1.0) had the lowest in 2003.

(3) The access to sound money component score is determined by measuring the change in the annual growth of the money supply vs the GDP, the inflation rate and its variability, and the freedom of the country's citizens to own foreign currency. Panama and the United States scored the highest on the access to sound money component in 2003 (9.8), while Zimbabwe (1.3) was ranked as the lowest scoring country.

(4) The freedom to trade with foreigners component score measures taxes on international trade, institutionalized trade barriers, total amount of trade compared to the expected amount [based on the country's population size, geographical area, miles of coastline and location (Akhter, 2004)], whether there is a significant gap between any official exchange rate and the black market rate, and controls on citizens' ability to trade in international capital markets. Hong Kong (9.7) and Singapore (9.5) had the highest scores on this component, with Burundi (3.2) and Myanmar (1.9) earning the lowest scores.

(5) The regulation component includes indicators from the credit, labor and financial markets. Credit market indicators include degree of private bank ownership, the ability of banks to compete freely on the foreign market, the depth and extent of private credit and whether a country has fixed interest rates. Labor market indicators include the effect of minimum wage laws, the extent to which employees can be freely hired and fired, union activity, unemployment benefits and mandatory military service. Business market indicators include price controls, difficulty of starting a new business, and time spent by executives dealing with government officials and corruption. Higher scores imply less regulation. Hong Kong (8.2) and Iceland (7.9) had the highest scores on this component in 2003, while Mozambique and Syria had the lowest (3.7).

\section{Other covariates}

We used the polity score to measure the extent of each country's political openness. The polity score was calculated by subtracting the country's level of autocracy (lack of competition in politics, few restraints on the executive branch, barriers to political participation and executive recruitment) from its level of democracy (competitive political participation, executive restraints, civil liberties for all). These data were obtained from the Center for International Development and Conflict Management's (2005) Polity IV Project. Previous research assessing the impact of democratic institutions has also preferred the polity measure to the democracy measure (Reuveny and $\mathrm{Li}, 2003$ ). The polity score ranges from -10 to 10 with a higher score signifying more open political institutions. Because of a non-normal distribution, the polity score was divided 
into three categories of high (9 to 10 ), middle ( 7 to 8 ) and low ( -10 to 6 ). For the purposes of our analysis, low polity was the reference group.

In addition to the polity score, we controlled for several other potential confounding variables. Data on total population, rural population as a proportion of the total population and average fertility rate were obtained through the World Bank's WDI database (World Bank, 2005). National GDP in purchasing power parities (PPPs) expressed in constant 2000 international dollars was also obtained from the WDI database (World Bank, 2005). We also included dummy variables for each five-year time interval (using 1980-1984 as the reference group), consistent with previous longitudinal studies in this field that have included dummy time variables to account for changes in child mortality over time (Wennemo, 1993; Judge, 1995; Mellor and Milyo, 2001; Gravelle et al., 2002).

\section{Covariates used in secondary analysis}

Income distribution. We used the Gini coefficient to measure within-country income distribution. The Gini is measured on a scale of 0 to 1 , where 0 represents perfect equality and 1 represents perfect inequality. It is the ratio of the area between the actual income distribution line (called the Lorenz curve) and the line of perfect equality (a line drawn at $45^{\circ}$ angle to the horizontal axis) to the entire area under the $45^{\circ}$ line. Data were obtained from the United Nations University, World Institute for Development Economics Research (2005) (UNU-WIDER) World Income Inequality Database version 2a (WIID2a). Only observations from samples with full area, population and age coverage for the country were included in our analysis. In the case of two or more entries in the same year for the same country, the higher quality observation was preferred, followed by observations gathered using similar definitions for income and measurement unit.

Social capital. Social capital was measured as the per cent of people who answered the question "Generally speaking, would you say that most people can be trusted or that you can't be too careful in dealing with people?" by responding "Most people can be trusted", following previous research in this field (Kawachi et al., 1997; Kennelly et al., 2003). A higher number therefore indicates more social capital. These data come from the World Values Surveys and European Values Surveys (Inglehart, 2004), which were conducted in four waves beginning in the early 1980s.

Female literacy. Female literacy was defined as the per cent of females aged 15 or older who "can, with understanding, both read and write a short, simple statement related to their everyday life" [United Nations Development Programme (UNDP), 1995, 1999, 2000, 2001, 2006]. Female literacy may be a confounder of the relation between neo-liberalism and infant or child mortality, as countries with more neo-liberal practices may have higher levels of literacy (Grubel, 1998; Esposto and Zaleski, 1999) and higher levels of female literacy 
and education are associated with decreased child mortality (Grosse and Auffrey, 1989; Martyn, 2004; Mogford, 2004; Schell et al., 2007). These analyses were restricted to the 1990-2004 time period because of limited availability of adult female literacy data before 1990 .

\section{Data analysis}

Analyses were conducted on 119 World Bank member countries (World Bank, 2007) for which data were available for all measures of interest in at least one time interval (countries included in the analysis are listed in the Appendix). Since data were available in different years for different countries, we calculated interval averages for five-year periods between 1980 and 2004, with a total of 464 observations contributed by the 119 countries. The five time intervals were 1980-1984, 1985-1989, 1990-1994, 1995-1999 and 2000-2004. We examined all variable distributions for outliers and normality. In the case of nonnormal distributions (for under-five mortality, total population and GDP) we used natural log transformations. We calculated summary statistics for each variable of interest, including mean, standard deviation, minimum and maximum values. We ran bivariate and multivariable regression analyses with child mortality as the outcome, using generalized estimating equations to adjust for repeated measures on each country over time. We performed separate multivariable analyses for each domain of neo-liberal policy (size of government, legal structure, sound money, trade and regulation) as well as the aggregate EFW index. Results were considered significant at the $\mathrm{p}<0.05$ level.

In order to assess whether neo-liberal practices had differential effects in rich vs poor countries, as has been suggested in some studies looking at the relations between neo-liberalism and outcomes other than health (e.g. Graeff and Mehlkop, 2003), we stratified the overall country set into two subsets based on gross national income (GNI) per capita and repeated all analyses. Sixty-three countries classified by the World Bank as low ( $\leqslant$ US \$765) or lower-middle income (US \$766-\$3034), based on 2003 GNI per capita, were classified in our analysis as low-income countries, whereas, fifty-six countries classified as uppermiddle (US \$3035-\$9385) or high-income countries ( $\geqslant$ US \$9386) by the World Bank were classified as high-income countries in our analysis (World Bank, 2005). Although in earlier intervals GNI per capita in an individual country may have fallen above or below the level of US \$3035 used to distinguish low and high-income countries in this analysis, each country's status remained fixed for the purpose of the analysis across all time intervals based on the 2003 classifications.

The primary analysis included controls for neo-liberal practices, as well as polity, total population, rural population, fertility, GDP per capita and time interval. We also performed secondary analyses that included additional controls for income inequality, social capital and female literacy in multivariable models. The inclusion 
of these three variables further restricted the sample to 60 countries, with a total of 107 observations, because of limited availability of these data. Because of the smaller sample size, the secondary analyses were conducted among all countries, without disaggregation by income group. The country intervals included in this secondary analysis are indicated in the Appendix.

We carried out four additional sensitivity analyses to assess the robustness of our results. In the first and second sensitivity analyses, we used male and female working-age mortality rates, respectively, as the outcome of interest. Workingage mortality data were collected from the World Bank's WDI database, with working-age mortality defined as "the probability of dying between the ages of 15 and $60 \ldots$ if subject to current age-specific mortality rates between those ages" (World Bank, 2005). Effects of country-wide practices on working-age mortality may differ from effects on childhood mortality because different processes are involved (e.g. non-communicable diseases in working-age mortality vs communicable diseases in child mortality) (Murray and Lopez, 1997); additionally, greater variability in working-age than child mortality exists, especially across high-income countries, where levels of child mortality are low, enhancing the ability to detect effects. Third, we restricted the analyses to the highest income countries, those with 2003 GNI per capita greater than US \$9385, which are classified as high-income by the World Bank, to assess whether relations between neo-liberal practices and population health may be different in these countries, as prior studies have suggested determinants of mortality in high-income countries differ from those in low- and middle-income countries (e.g. Lindstrom and Lindstrom, 2006; Schell et al., 2007). Fourth, we excluded the United States from all analyses, as it has been shown to be an outlier in other studies including national income as a predictor of population health (e.g. Reinhardt et al., 2002).

\section{Results}

\section{Descriptive statistics}

Descriptive statistics for all variables included in the primary analysis are shown in Table 1. The average under-five mortality rate across all countries during 1980-2004 was 67.5 deaths per 1000 live births; low-income countries had higher average child mortality rates than high-income countries. The EFW index averaged 5.8 across all countries, with lower scores in low-income than highincome countries, particularly for the component scores of legal structure and property rights, access to sound money, freedom to trade and regulation of credit, labor and business. Over sixty per cent $(62.0 \%)$ of high-income countries had high polity scores, compared to less than one-tenth $(8.4 \%)$ of low-income countries. Compared to high-income countries, low-income countries included in the analysis had larger populations, greater proportions of the population living in rural areas, and higher fertility from 1980 to 2004. 
Table 1. Descriptive statistics of dependent variable, explanatory variables and control variables for primary analyses, 1980-2004

\begin{tabular}{|c|c|c|c|c|c|c|c|c|c|c|c|c|}
\hline & \multicolumn{4}{|c|}{ All countries $(N=119)$} & \multicolumn{4}{|c|}{ Low-income countries $(N=63)^{a}$} & \multicolumn{4}{|c|}{ High-income countries $(N=56)^{a}$} \\
\hline & Mean & $\begin{array}{l}\text { Standard } \\
\text { deviation }\end{array}$ & Minimum & Maximum & Mean & $\begin{array}{l}\text { Standard } \\
\text { deviation }\end{array}$ & Minimum & Maximum & Mean & $\begin{array}{l}\text { Standard } \\
\text { deviation }\end{array}$ & Minimum & Maximum \\
\hline \multicolumn{13}{|l|}{ Dependent variable } \\
\hline $\begin{array}{l}\text { Under-five mortality rate, } \\
\text { per } 1000 \text { live births }\end{array}$ & 67.5 & 72.7 & 3.9 & 336.0 & 114.0 & 73.5 & 16.4 & 336.0 & 17.5 & 18.0 & 3.9 & 115.0 \\
\hline \multicolumn{13}{|l|}{ Explanatory variables $^{\mathrm{b}}$} \\
\hline EFW index & 5.8 & 1.3 & 2.3 & 8.8 & 5.1 & 1.0 & 2.3 & 7.2 & 6.5 & 1.1 & 3.3 & 8.8 \\
\hline Size of government & 5.4 & 1.6 & 1.6 & 9.1 & 5.6 & 1.6 & 1.6 & 9.1 & 5.2 & 1.6 & 1.8 & 8.4 \\
\hline $\begin{array}{l}\text { Legal structure and security of } \\
\text { property rights }\end{array}$ & 5.6 & 1.9 & 1.7 & 9.4 & 4.3 & 1.3 & 1.7 & 7.9 & 6.9 & 1.5 & 1.8 & 9.4 \\
\hline Access to sound money & 6.7 & 2.3 & 0.0 & 9.8 & 5.8 & 2.2 & 0.0 & 9.6 & 7.7 & 2.0 & 1.7 & 9.8 \\
\hline $\begin{array}{l}\text { Freedom to exchange with } \\
\text { foreigners }\end{array}$ & 6.4 & 1.5 & 1.7 & 9.6 & 5.6 & 1.3 & 1.7 & 8.3 & 7.2 & 1.2 & 3.1 & 9.6 \\
\hline $\begin{array}{l}\text { Regulation of credit, labor } \\
\text { and business }\end{array}$ & 5.5 & 1.0 & 2.5 & 8.8 & 5.1 & 0.9 & 2.5 & 7.2 & 6.0 & 0.9 & 3.4 & 8.8 \\
\hline \multicolumn{13}{|l|}{ Control variables } \\
\hline Polity categories ${ }^{\mathrm{c}}$ & $\begin{array}{l}\% \text { of } \\
\text { total }\end{array}$ & & & & $\begin{array}{l}\% \text { of } \\
\text { total }\end{array}$ & & & & $\begin{array}{l}\% \text { of } \\
\text { total }\end{array}$ & & & \\
\hline Low polity $(\leqslant 6)$ & 52.2 & & & & 74.4 & & & & 28.8 & & & \\
\hline Medium polity $(7-8)$ & 13.4 & & & & 17.2 & & & & 9.3 & & & \\
\hline High polity $(9-10)$ & 34.5 & & & & 8.4 & & & & 62.0 & & & \\
\hline $\begin{array}{l}\text { Total population, in tens } \\
\text { of millions }\end{array}$ & 4.3 & 14.0 & 0.0 & 128.0 & 6.3 & 18.9 & 0.1 & 128.0 & 2.3 & 4.4 & 0.0 & 28.8 \\
\hline $\begin{array}{l}\text { Rural population, as proportion } \\
\text { of total }\end{array}$ & 0.4 & 0.2 & 0.0 & 1.0 & 0.6 & 0.2 & 0.2 & 1.0 & 0.3 & 0.2 & 0.0 & 0.8 \\
\hline Fertility & 3.4 & 1.8 & 1.2 & 8.0 & 4.6 & 1.7 & 1.2 & 8.0 & 2.2 & 1.0 & 1.2 & 7.0 \\
\hline $\begin{array}{l}\text { GDP per capita, PPP, in constant } \\
2000 \text { international dollars }\end{array}$ & 9826.9 & 9400.3 & 496.0 & $52,771.7$ & 2957.8 & 2089.4 & 496.0 & 9974.2 & $17,060.7$ & 8646.8 & 2783.2 & $52,771.7$ \\
\hline
\end{tabular}




\begin{tabular}{lrrr} 
Time intervals & \% of & \% of & $\%$ of \\
& total & total & 21.0 \\
total & 20.8 \\
$1980-1984$ & 20.9 & 0.8 & 8.4 \\
$1985-1989$ & 4.5 & 25.2 & 21.2 \\
$1990-1994$ & 23.3 & 26.5 & 24.8 \\
$1995-1999$ & 25.7 & 26.5 & 24.8 \\
$2000-2004$ & 25.7 & \\
\hline \hline
\end{tabular}

EFW = Economic Freedom of the World index; GDP = gross domestic product; PPP = purchasing power parities.

a"High-income countries" are those classified by the World Bank as "upper-middle" or "high" income countries according to 2003 GNI (gross national income) per capita; "low-income countries" are those classified as "lower-middle" or "low" income.

bAll components of the EFW index are measured on a scale of 0 to 10; a higher score indicates a more neo-liberal outlook.

${ }^{\mathrm{c}}$ Measured on a scale of -10 to 10 ; a higher score indicates more open political institutions. 


\section{Primary analysis}

In bivariate analyses, all explanatory and control variables were significantly associated with under-five mortality $(\mathrm{p}<0.01)$ across the 119 countries studied. Specifically, higher levels of neo-liberalism, polity, population size and GDP per capita were associated with lower child mortality rates, whereas higher rural population and fertility were associated with higher mortality rates. Mortality rates decreased over time, as indicated by negative coefficients for each time interval in comparison to the 1980-1984 time interval.

In adjusted multivariable models (Table 2), the EFW index score was not significantly associated with under-five mortality in any of the country groups (all countries, high-income, low-income). As for the components of the EFW index, higher scores on property rights and the access to sound money components were significantly associated with lower under-five mortality among all countries $(\mathrm{p}=0.017$ and $\mathrm{p}=0.024$, respectively), and less market regulation, indicated by higher scores on the regulation of credit, labor and business component, was significantly associated with lower mortality in high-income countries $(p=0.001)$. None of the EFW component scores were significantly associated with under-five mortality among low-income countries.

Among all countries from 1980 to 2004, lower fertility rates and higher GDP per capita were associated with lower child mortality ( $p<0.001$ for both). These associations remained in the analyses for high-income and low-income countries. Medium levels of polity as compared to low polity were associated with lower mortality among low-income countries. The decline in child mortality over time among all countries was confirmed with significant negative associations between the dummy variables representing five-year periods and child mortality starting with the 1990-1994 period (compared to the 1980-1984 reference period).

\section{Secondary analysis with additional covariates}

In adjusted multivariable models controlling for Gini coefficient, social capital and female literacy (Table 3), the EFW index score was not significantly associated with child mortality but the sound money component of the score was negatively associated with child mortality (as in the more parsimonious analysis). Lower income inequality and smaller population were associated with lower child mortality among all countries as were higher levels of social capital and female literacy. Dummy variables representing time since the 1990-1994 reference period were also negative and significant predictors of child mortality.

\section{Sensitivity analyses}

We conducted several sensitivity analyses to assess the robustness of the results of the primary analysis described above to different outcomes, model specifications and samples. We summarize the results of these sensitivity analyses here; detailed results and tables are available from the authors upon request. 
Table 2. Multivariable models predicting log of under-five mortality rate, 1980-2004

\begin{tabular}{|c|c|c|c|c|c|c|c|c|c|c|c|c|c|c|c|c|c|c|c|}
\hline & \multicolumn{3}{|c|}{ EFW index } & \multicolumn{3}{|c|}{ Size of government } & \multicolumn{3}{|c|}{$\begin{array}{c}\text { Legal structure and security } \\
\text { of property rights }\end{array}$} & \multicolumn{3}{|c|}{ Access to sound money } & \multicolumn{3}{|c|}{$\begin{array}{c}\text { Freedom to exchange with } \\
\text { foreigners }\end{array}$} & \multicolumn{3}{|c|}{$\begin{array}{c}\text { Regulation of credit, labor } \\
\text { and business }\end{array}$} & \\
\hline & Beta & $\begin{array}{l}\text { Standard } \\
\text { error }\end{array}$ & $\mathrm{p}$-value & Beta & $\begin{array}{l}\text { Standard } \\
\text { error }\end{array}$ & p-value & Beta & $\begin{array}{l}\text { Standard } \\
\text { error }\end{array}$ & p-value & Beta & $\begin{array}{l}\text { Standard } \\
\text { error }\end{array}$ & p-value & Beta & $\begin{array}{l}\text { Standard } \\
\text { error }\end{array}$ & p-value & Beta & $\begin{array}{l}\text { Standard } \\
\text { error }\end{array}$ & p-value & \\
\hline \multicolumn{20}{|l|}{$\begin{array}{l}\text { All countries } \\
\qquad(N=119)\end{array}$} \\
\hline $\begin{array}{l}\text { EFW component }{ }^{\mathrm{a}} \\
\text { Polity }\end{array}$ & -0.027 & 0.019 & 0.148 & 0.018 & 0.012 & 0.126 & -0.031 & 0.013 & 0.017 & -0.017 & 0.007 & 0.024 & -0.012 & 0.016 & 0.437 & -0.032 & 0.018 & 0.068 & Z \\
\hline Medium & -0.075 & 0.042 & 0.073 & -0.076 & 0.042 & 0.071 & -0.060 & 0.036 & 0.101 & -0.081 & 0.042 & 0.052 & -0.074 & 0.042 & 0.077 & -0.068 & 0.042 & 0.104 & \\
\hline High & -0.093 & 0.060 & 0.124 & -0.102 & 0.059 & 0.082 & -0.078 & 0.059 & 0.189 & -0.093 & 0.060 & 0.121 & -0.098 & 0.061 & 0.111 & -0.090 & 0.060 & 0.131 & 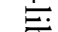 \\
\hline $\begin{array}{l}\text { Total population, } \\
\text { in tens of } \\
\text { millions, logged }\end{array}$ & 0.033 & 0.022 & 0.132 & 0.033 & 0.022 & 0.128 & 0.024 & 0.023 & 0.279 & 0.034 & 0.022 & 0.114 & 0.034 & 0.022 & 0.112 & 0.028 & 0.022 & 0.206 & 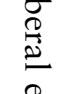 \\
\hline $\begin{array}{l}\text { Rural population, } \\
\text { as proportion of } \\
\text { total }\end{array}$ & 0.123 & 0.231 & 0.593 & 0.087 & 0.230 & 0.705 & 0.178 & 0.227 & 0.433 & 0.148 & 0.231 & 0.522 & 0.112 & 0.233 & 0.632 & 0.106 & 0.234 & 0.651 & రి \\
\hline Fertility & 0.144 & 0.025 & $<0.001$ & 0.144 & 0.025 & $<0.001$ & 0.127 & 0.024 & $<0.001$ & 0.149 & 0.025 & $<0.001$ & 0.137 & 0.026 & $<0.001$ & 0.136 & 0.026 & $<0.001$ & . \\
\hline $\begin{array}{l}\text { GDP per capita, } \\
\text { PPP, logged }\end{array}$ & -0.666 & 0.059 & $<0.001$ & -0.689 & 0.057 & $<0.001$ & -0.693 & 0.049 & $<0.001$ & -0.659 & 0.059 & $<0.001$ & -0.682 & 0.057 & $<0.001$ & -0.684 & 0.061 & $<0.001$ & $\tilde{7}$ \\
\hline Time interval $^{\mathrm{d}}$ & & & & & & & & & & & & & & & & & & & \\
\hline 1985-1989 & -0.059 & 0.035 & 0.088 & -0.072 & 0.036 & 0.046 & -0.087 & 0.034 & 0.009 & -0.058 & 0.033 & 0.082 & -0.061 & 0.036 & 0.084 & -0.043 & 0.029 & 0.129 & \\
\hline 1990-1994 & -0.207 & 0.024 & $<0.0001$ & -0.231 & 0.024 & $<0.001$ & -0.247 & 0.023 & $<0.001$ & -0.209 & 0.024 & $<0.001$ & -0.217 & 0.023 & $<0.001$ & -0.212 & 0.023 & $<0.001$ & D \\
\hline 1995-1999 & -0.253 & 0.037 & $<0.001$ & -0.297 & 0.034 & $<0.001$ & -0.296 & 0.031 & $<0.001$ & -0.261 & 0.033 & $<0.001$ & -0.269 & 0.033 & $<0.001$ & -0.259 & 0.033 & $<0.001$ & \\
\hline 2000-2004 & -0.335 & 0.049 & $<0.001$ & -0.398 & 0.043 & $<0.001$ & -0.402 & 0.038 & $<0.001$ & -0.332 & 0.045 & $<0.001$ & -0.360 & 0.043 & $<0.001$ & -0.347 & 0.042 & $<0.001$ & है \\
\hline $\begin{array}{l}\text { Low-income } \\
\quad \text { countries }(\mathrm{N}=63)^{e}\end{array}$ & & & & & & & & & & & & & & & & & & & 官 \\
\hline $\begin{array}{l}\text { EFW component }{ }^{\mathrm{a}} \\
\text { Polity }{ }^{\mathrm{b}}\end{array}$ & -0.024 & 0.023 & 0.295 & 0.009 & 0.015 & 0.541 & -0.014 & 0.013 & 0.302 & -0.013 & 0.010 & 0.172 & -0.026 & 0.020 & 0.193 & 0.005 & 0.023 & 0.832 & $\stackrel{E}{\partial}$ \\
\hline Medium & -0.102 & 0.044 & 0.022 & -0.103 & 0.045 & 0.022 & -0.103 & 0.046 & 0.024 & -0.107 & 0.043 & 0.013 & -0.095 & 0.046 & 0.039 & -0.080 & 0.044 & 0.069 & $\overline{0}$ \\
\hline High & 0.008 & 0.060 & 0.889 & -0.001 & 0.063 & 0.985 & 0.005 & 0.068 & 0.943 & 0.011 & 0.059 & 0.857 & 0.006 & 0.062 & 0.925 & 0.009 & 0.061 & 0.879 & \\
\hline $\begin{array}{l}\text { Total population, } \\
\text { in tens of } \\
\text { millions, logged }\end{array}$ & 0.042 & 0.028 & 0.142 & 0.042 & 0.029 & 0.143 & 0.046 & 0.030 & 0.121 & 0.043 & 0.028 & 0.123 & 0.045 & 0.028 & 0.106 & 0.041 & 0.029 & 0.148 & 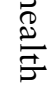 \\
\hline
\end{tabular}


Table 2. (Continued)

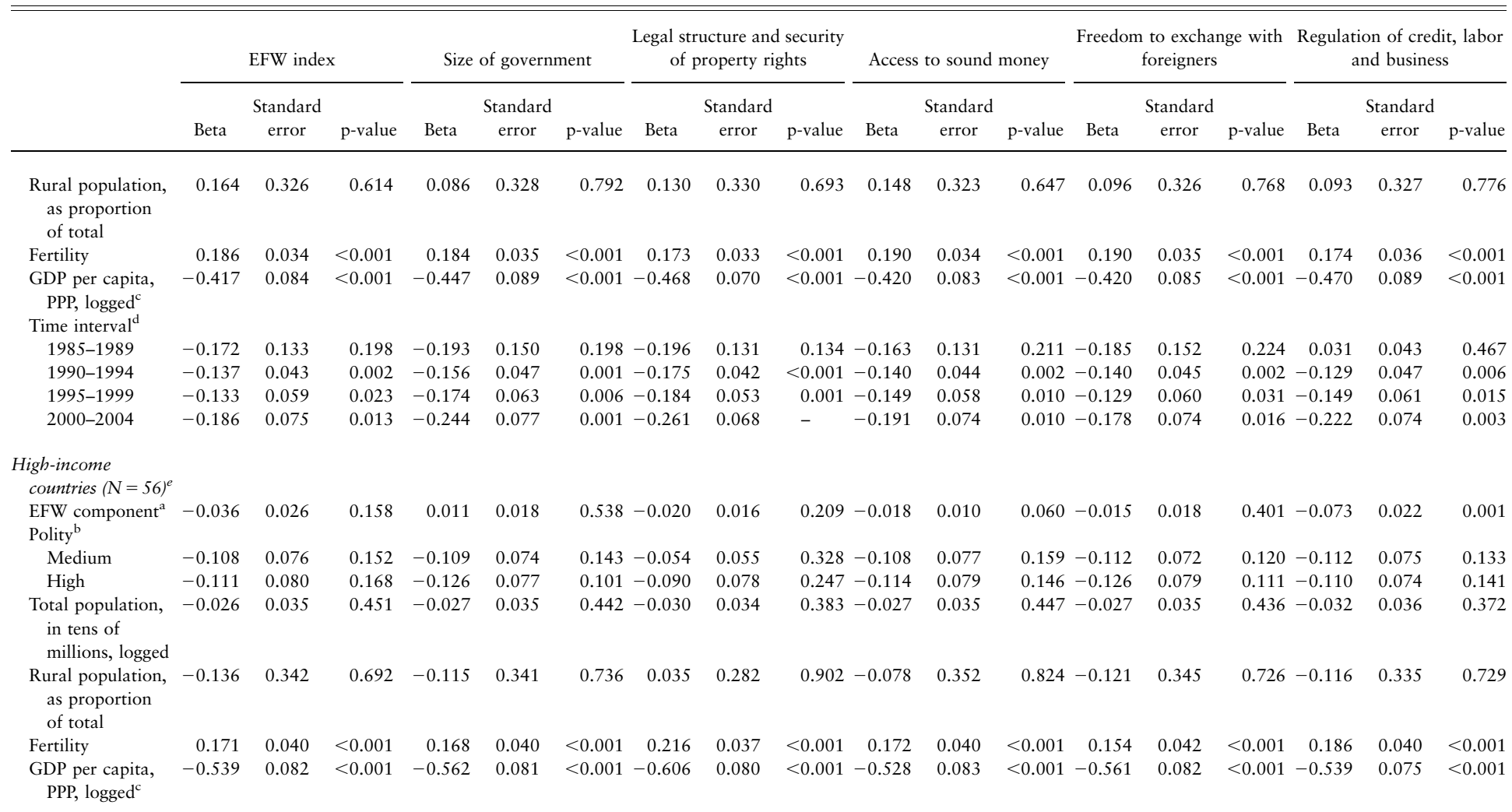




\begin{tabular}{|c|c|c|c|c|c|c|c|c|c|c|c|c|c|c|}
\hline \multicolumn{15}{|l|}{ Time interval $^{\mathrm{d}}$} \\
\hline 1985-1989 & -0.088 & 0.031 & 0.005 & -0.096 & 0.031 & $0.002-0.101$ & 0.032 & $0.002-0.089$ & 0.031 & $0.004-0.091$ & 0.031 & $0.003-0.104$ & 0.029 & $<0.001$ \\
\hline 1990-1994 & -0.249 & 0.031 & $<0.001$ & -0.276 & 0.028 & $<0.001-0.287$ & 0.028 & $<0.001-0.258$ & 0.028 & $<0.001-0.266$ & 0.029 & $<0.001-0.264$ & 0.025 & $<0.001$ \\
\hline 1995-1999 & -0.346 & 0.046 & $<0.001$ & -0.387 & 0.043 & $<0.001-0.373$ & 0.040 & $<0.001-0.356$ & 0.041 & $<0.001-0.368$ & 0.042 & $<0.001-0.331$ & 0.044 & $<0.001$ \\
\hline 2000-2004 & -0.472 & 0.062 & $<0.001$ & -0.530 & 0.057 & $<0.001-0.499$ & 0.056 & $<0.001-0.480$ & 0.055 & $<0.001-0.507$ & 0.057 & $<0.001-0.458$ & 0.055 & $<0.001$ \\
\hline
\end{tabular}

$\mathrm{EFW}=$ Economic Freedom of the World index; GDP $=$ gross domestic product; $\mathrm{PPP}=$ purchasing power parities.

${ }^{a}$ All components of the EFW index are measured on a scale of 0 to 10 ; a higher score indicates a more neo-liberal outlook.

${ }^{b}$ Measured on a scale of -10 to 10 ; a higher score indicates more open political institutions. Low polity is the reference group.

${ }^{\mathrm{c}} \mathrm{GDP}$ per capita, PPP, was expressed in constant 2000 international dollars before natural log transformation.

'The 1980-1984 interval is the reference group.

e"High-income countries" are those classified by the World Bank as "upper-middle" or "high" income countries according to 2003 GNI (gross national income) per capita; "low-income countries" are those classified as "lower-middle" or "low" income. 
Table 3. Multivariable models predicting log of under-five mortality rate, including adjustment for Gini coefficient, social capital and female literacy, 1990-2004

\begin{tabular}{|c|c|c|c|c|c|c|c|c|c|c|c|c|c|c|c|c|c|c|}
\hline & \multicolumn{3}{|c|}{ EFW index } & \multicolumn{3}{|c|}{ Size of government } & \multicolumn{3}{|c|}{$\begin{array}{l}\text { Legal structure and security } \\
\text { of property rights }\end{array}$} & \multicolumn{3}{|c|}{$\begin{array}{l}\text { Access to sound } \\
\text { money }\end{array}$} & \multicolumn{3}{|c|}{$\begin{array}{l}\text { Freedom to exchange } \\
\text { with foreigners }\end{array}$} & \multicolumn{3}{|c|}{$\begin{array}{l}\text { Regulation of credit, labor } \\
\text { and business }\end{array}$} \\
\hline & & Standard & & & Standard & & & Standard & & & Standard & & & Standard & & & Standard & \\
\hline & Beta & error & $\mathrm{p}$-value & Beta & error & $\mathrm{p}$-value & Beta & error & $\mathrm{p}$-value & Beta & error & $\mathrm{p}$-value & Beta & error & $\mathrm{p}$-value & Beta & error & $\mathrm{p}$-value \\
\hline \multicolumn{19}{|l|}{$\begin{array}{l}\text { All countries } \\
\quad(N=60)\end{array}$} \\
\hline EFW component ${ }^{\mathrm{a}}$ & -0.058 & 0.032 & 0.071 & 0.018 & 0.024 & 0.459 & 0.005 & 0.032 & 0.888 & -0.044 & 0.010 & $<0.001$ & 0.005 & 0.030 & 0.877 & -0.024 & 0.034 & 0.487 \\
\hline Gini coefficient & 1.104 & 0.518 & 0.033 & 0.950 & 0.512 & 0.064 & 1.069 & 0.503 & 0.034 & 0.893 & 0.498 & 0.073 & 1.081 & 0.516 & 0.036 & 1.110 & 0.504 & 0.028 \\
\hline Social capital $^{\mathrm{b}}$ & -0.471 & 0.238 & 0.048 & -0.488 & 0.242 & 0.044 & -0.520 & 0.250 & 0.038 & -0.492 & 0.223 & 0.027 & -0.506 & 0.242 & 0.037 & -0.501 & 0.241 & 0.038 \\
\hline Female literacy & -0.008 & 0.004 & 0.018 & -0.008 & 0.004 & 0.042 & -0.008 & 0.004 & 0.038 & -0.009 & 0.003 & 0.006 & -0.008 & 0.004 & 0.031 & -0.008 & 0.004 & 0.026 \\
\hline \multicolumn{19}{|l|}{ Polity $^{\mathrm{c}}$} \\
\hline Medium & 0.037 & 0.060 & 0.534 & 0.044 & 0.057 & 0.445 & 0.043 & 0.058 & 0.458 & 0.036 & 0.058 & 0.537 & 0.044 & 0.057 & 0.437 & 0.037 & 0.061 & 0.549 \\
\hline High & -0.027 & 0.087 & 0.752 & -0.030 & 0.092 & 0.742 & -0.040 & 0.086 & 0.642 & -0.001 & 0.090 & 0.991 & -0.039 & 0.087 & 0.659 & -0.041 & 0.088 & 0.641 \\
\hline $\begin{array}{l}\text { Total } \\
\text { population, in } \\
\text { tens of millions, } \\
\text { logged }\end{array}$ & 0.060 & 0.026 & 0.024 & 0.058 & 0.027 & 0.030 & 0.061 & 0.026 & 0.019 & 0.062 & 0.026 & 0.016 & 0.060 & 0.026 & 0.022 & 0.059 & 0.026 & 0.024 \\
\hline $\begin{array}{l}\text { Rural } \\
\text { population, as } \\
\text { proportion of } \\
\text { total }\end{array}$ & 0.168 & 0.291 & 0.564 & 0.154 & 0.290 & 0.596 & 0.149 & 0.301 & 0.620 & 0.231 & 0.297 & 0.437 & 0.158 & 0.291 & 0.587 & 0.163 & 0.293 & 0.579 \\
\hline Fertility & 0.215 & 0.058 & $<0.001$ & 0.191 & 0.054 & $<0.001$ & 0.189 & 0.059 & 0.001 & 0.231 & 0.052 & $<0.001$ & 0.189 & 0.055 & 0.001 & 0.202 & 0.058 & 0.001 \\
\hline $\begin{array}{l}\text { GDP per capita, } \\
\text { PPP, logged }\end{array}$ & -0.509 & 0.101 & $<0.001$ & -0.593 & 0.088 & $<0.001$ & -0.592 & 0.121 & $<0.001$ & -0.488 & 0.082 & $<0.001$ & -0.586 & 0.085 & $<0.001$ & -0.557 & 0.097 & $<0.001$ \\
\hline \multicolumn{19}{|l|}{ Time interval $^{\mathrm{e}}$} \\
\hline 1995-1999 & -0.108 & 0.033 & 0.001 & -0.123 & 0.033 & $<0.001$ & -0.122 & 0.037 & 0.001 & -0.124 & 0.029 & $<0.001$ & -0.122 & 0.032 & $<0.001$ & -0.107 & 0.043 & 0.013 \\
\hline 2000-2004 & -0.191 & 0.048 & $<0.001$ & -0.247 & 0.048 & $<0.001$ & -0.232 & 0.044 & $<0.001$ & -0.161 & 0.045 & $<0.001$ & -0.237 & 0.044 & $<0.001$ & -0.216 & 0.053 & $<0.001$ \\
\hline
\end{tabular}

$\mathrm{EFW}=$ Economic Freedom of the World index; GDP = gross domestic product; PPP = purchasing power parities.

${ }^{a}$ All components of the EFW index are measured on a scale of 0 to 10 ; a higher score indicates a more neo-liberal outlook.

bProportion of participants in the World and European Values Surveys who responded to the question: 'Generally speaking, would you say that most people can be trusted or that you can't be too careful in dealing with people?' with 'Most people can be trusted'.

${ }^{\mathrm{c}}$ Measured on a scale of -10 to 10 ; a higher score indicates more open political institutions. Low polity is the reference group.

${ }^{\mathrm{d}}$ GDP per capita, PPP, was expressed in constant 2000 international dollars before natural log transformation.

${ }^{\mathrm{e}}$ The 1990-1994 interval is the reference group. 
All sensitivity analyses were done using the primary independent variable set (components of neo-liberal practices, as well as polity, total population, rural population, fertility, GDP per capita and time interval) from 1980 to 2004.

\section{Alternative health outcomes}

The average male and female working-age mortality rates across all countries during 1980-2004 were 255.9 and 187.3 deaths per 1000 population, respectively; low-income countries had higher average working-age mortality rates (339.1 for males and 276.6 for females, per 1000 population) than high-income countries (172.0 for males and 97.2 for females, per 1000 population). Relations between neo-liberal economic practices and male and female working-age mortality were similar to those in models with under-five mortality. Specifically, the EFW index was not associated with male or female working-age mortality. Improved access to sound money was associated with lower male mortality in all $(\mathrm{p}=0.005)$ and low-income countries $(\mathrm{p}=0.004)$. Security of property rights and less market regulation were associated with lower male mortality in highincome but not low-income countries (p-values of 0.003 and 0.004 , respectively). None of the EFW components were significantly associated with female working-age mortality. Higher GDP per capita was associated with lower male $(\mathrm{p}<0.001)$ and female $(\mathrm{p}<0.001)$ mortality and lower fertility rate was further associated with lower female mortality $(\mathrm{p}<0.001)$.

\section{Different country sets}

Restricting analyses to only countries defined by the World Bank as high-income [GNI per capita >US $\$ 9385$ in 2003 (World Bank, 2005)] resulted in 33 countries (indicated in the Appendix), and 147 country intervals. In these models, there were significant negative associations between the EFW index score $(\mathrm{p}=0.001)$, sound money $(\mathrm{p}=0.016)$ and market regulation $(\mathrm{p}=0.023)$ and child mortality. Again, this indicates that these more neo-liberal policies were associated with lower rates of child mortality. Excluding the United States from analyses resulted in a total of 118 countries ( 459 country intervals). There were no substantial differences in results after excluding the United States.

\section{Discussion}

The extant literature that has considered the relation between neo-liberal economic practices and population health is conflicting. Some studies have found a relation between higher scores on the EFW index and improved health, indicated by increased life expectancy (Grubel, 1998; Esposto and Zaleski, 1999). In contrast, Mehrtens (2004) observed an association between higher scores on the EFW index and poorer health, indicated by higher infant mortality rates, in adjusted models among 18 high-income countries. Others have reported similar 
negative effects of neo-liberalism on population health (Pampel and Pillai, 1986; Labra, 2002; Mehrtens, 2004; Cupples, 2005; Navarro et al., 2006). These different results might be explained by different study designs (cross-sectional vs our time-series analysis), the larger number of high-income countries included in our analysis and the different control variables used in our multivariable models.

Aiming to build on this work, we considered the relation between specific disaggregated features of neo-liberal economic practices and their relation to population health. Using a longitudinal cross-national analysis we found that certain domains of neo-liberal economic policy, specifically protection of property rights and access to sound money were associated with lower levels of child mortality among all countries over time. No neo-liberal economic policies were associated with child mortality in low-income countries. High-income countries characterized by less regulation of credit, labor and business had lower child mortality rates, as well as lower working-age male mortality, even after controlling for other covariates. Access to sound money was also associated with lower working-age male mortality.

The association between sound money supply and lower child mortality documented in our study may be explained by the deleterious effect of inflation on poor families. When the inflation rate is high, it can wipe out the savings of all but the richest members of society. The small buffer that separates the more vulnerable members of society from poverty or indigence is then removed, leaving them exposed and with no recourse should they fall ill, thus leading to higher child mortality rates. Similarly, better protection of property rights allows families greater security of tenure and permits them greater access to credit for economic and health investments, using property as collateral. In this respect, then, the observed associations between the property rights and sound money components of the EFW index and lower under-five mortality may reflect the centrality of family savings (not captured in typical measures of aggregate income) and property as protection against adverse circumstances and as positive influences on population health.

In high-income countries, the association between less regulation of credit, labor and business, as indicated by higher scores on the regulation component of the EFW index, and under-five mortality may be due to the impact of a favorable climate for private enterprise on employment opportunities. These opportunities may serve to provide ongoing employment and a steady income, which are associated with better population health (Ross and Mirowsky, 1995; Benzeval and Judge, 2001). The lack of this association in low-income countries may be testament to the many other barriers (including lack of education and financial capital) to such employment opportunities.

We did not find an association between government size and child mortality among countries included in the analysis, when controlling for other factors. Other studies that have examined the size of the welfare state or public health expenditures (important determinants of government size) and the association 
between government size and population health have found that higher levels of social welfare spending as a proportion of total government spending, and longer government by parties in favor of redistributive efforts, are associated with lower infant and post-neonatal mortality rates (Pampel and Pillai, 1986; Navarro et al., 2006).

We found no significant association between trade and population health. This concurs with previous research (Mehrtens, 2004; Moore et al., 2006) in high-income countries. However, the lack of association between higher levels of free trade and improved population health among low-income countries contrasts with previous cross-sectional findings suggesting that trade and foreign direct investment may bring improvements in infrastructure, such as better roads and telecommunication networks, and other technology spillovers essential to the promotion of population health in poorer countries (Blomstrom and Kokko, 1997). It is possible, however, that freer trade alone (rather than in combination with foreign direct investment), which in many poor countries means exports of raw or minimum value-added goods, will have limited effect on economic growth and national infrastructure.

We found a significant positive association between income inequality and child mortality in all countries. This is consistent with previous work on the subject, which has shown that increases in income inequality are associated with poorer population health (Rodgers, 1979; Kawachi et al., 1997; Flegg, 1982; Wilkinson, 1992). Higher levels of social capital were significantly associated with lower child mortality in our secondary analysis. Here, our research agrees with some earlier authors and contradicts others. For example, some studies focusing on associations within single countries have found the same protective relationship between social capital and population health (Kawachi et al., 1997). Other studies using a cross-national design have found no such association (Kennelly et al., 2003). The differences may be accounted for by differences in study design and samples of countries under study.

We did not find a robust association between openness of political institutions and health at any income level in adjusted models. When low-income countries were considered together, medium but not high levels of openness of political institutions were associated with lower child mortality. This may be because there were very few (eleven) low-income countries with high polity ratings. Other researchers have found that higher levels of democracy were associated with lower child mortality rates across countries (Franco et al., 2004).

Previous findings of a positive association between fertility and child mortality are confirmed in our study regardless of income level (Rutstein, 2000; El-Ghannam, 2003; Macinko et al., 2006). We also found a strong negative relationship between absolute wealth, as indicated by GDP per capita, and child mortality in both high- and low-income countries, consistent with previous research (Hales et al., 1999; Beckfield, 2004; Chung and Muntaner, 2007). 


\section{Study limitations}

Several limitations of this study should be considered when interpreting the results. The first limitation involves comparability of the data. When collecting cross-national data, comparability of sources is always a concern. Different countries may collect data differently and in such a way that they are reporting on very different phenomena, although the indicators share a common name. For example, the WIID2a income distribution database, from which we obtained the Gini coefficient estimates, includes observations from several types of surveys, many of which measure income according to different definitions. Some surveys measured net income, while others included gross measures or relied on consumption patterns rather than monetary income. While every effort was made to include data with consistent definitions, the scarcity of data made it impossible to include only observations collected using entirely consistent methodologies.

Another limitation was data availability. Many of the variables were missing entirely for some countries or were available only intermittently from 1980 to 2004. Income distribution data had been poorly documented, especially for low-income countries, and especially prior to the 1990s. Social capital is a relatively new theoretical concept, and no cross-national data exists prior to the early 1980s. Similarly, female literacy data was only available after 1990. These three variables limited the sample size of our secondary analysis; results of that analysis may reflect the selected nature of the countries with available data as well as reduced power to identify significant effects. In addition, many low-income countries report health statistics only every five or ten years, which decreased the number of observations in our study. Therefore, inference about non-significant associations should be drawn with caution from these data.

Finally, the EFW index is one particular operationalization of neo-liberal economic policies and practices. Previous studies have quantified neoliberal practices and economic globalization using measures of inflation, market regulation, government transfers and trade openness (e.g. Labao and Hooks, 2003; Gerring and Thacker, 2005; Gerring and Thacker, 2008). These components of neoliberalism and globalization, considered essential to evaluations of the effects of these practices on economic growth and human development (Gerring and Thacker, 2005; Gerring and Thacker, 2008), are included in the EFW index, as described above, and were evaluated separately using the five components of the EFW index. Other measures of economic freedom include Freedom House's Economic Freedom Indicators (Messick, 1996) and the Heritage Foundation's Indices of Economic Freedom (O'Driscoll et al., 2001). Although these measures include components similar to those included in the EFW index, the Freedom House indicators emphasize civil liberties whereas the Heritage Foundation indices emphasize development assistance; however, these alternate measures of economic freedom are highly correlated with the EFW index and produce 
similar rankings of countries (Hanke and Walters, 1997). Both the EFW index and the Heritage Foundation indices incorporate information on the stability of each country's monetary supply and the size of government, characteristics that are central to discussions of the relation between neo-liberal practices and population health (Coburn, 2000). The EFW index, with data available from the 1970s, is available for a longer time span than the Heritage Foundation indices, which began in 1994, making it a superior choice for longitudinal analysis. Furthermore, our desire to conduct a cross-national analysis quantifying the relation between neo-liberal economic policies and practices argued against grouping countries according to type of government policies (e.g. Navarro et al., 2006) or using other measures of neo-liberal reform that have only been developed for limited country sets [e.g. Latin American countries in Huber and Solt (2004)], reinforcing our decision to use the EFW index and its components as the explanatory variables of interest in this analysis. Although the EFW index was better suited to the objectives of this analysis than other measures of economic freedom or indicators of neo-liberalism and globalization, some aspects of neo-liberal policies that have been linked to health outcomes, including structural adjustment programs (Breman and Shelton, 2007), were not included in this measure. Thus, the conclusions drawn here may only apply to the aspects of neo-liberalism incorporated in the EFW index. Importantly, the neoliberalism variables included here are themselves composite measures of many separate policy and economic factors, some of which may act in opposite directions on child mortality. While our interest here was in capturing the influence of several components of neo-liberal policy, further disaggregation into specific subcomponents of business and government behavior would be instructive.

\section{Conclusion}

Three central findings emerge from our results. Access to sound money had the single-most robust association with lower under-five mortality across countries in all analyses. Protection of property rights was also associated with lower under-five mortality in all countries in the more parsimonious analyses (not adjusting for income inequality, social capital or female literacy). Both these policy areas can theoretically be linked with better economic prospects for households that may, in turn, lead to improved health outcomes.

Among more developed countries (i.e. those with average incomes above approximately US \$3000), less market regulation was also associated with lower child and adult male mortality. It is plausible that in these countries, the majority of which already have basic infrastructure and other determinants of health (e.g. closed sewers, treated water systems, quality health care) in place and thus relatively good population health, a more robust private enterprise may further improve health. 
Among low-income countries, none of the neo-liberal policies examined were associated with child mortality. In these countries, where large portions of the population may lack even the most basic health infrastructure, the greater individual economic freedom allowed by neo-liberal economic practices may do little to offset the lack of fundamental determinants of health from proper nutrition to clean water to functioning health systems. However, we failed to find any evidence that neo-liberal practices and policies were independently associated with poorer population health using the EFW measures of neo-liberalism. Importantly, we did not assess the impact of neoliberal policy on equality in health outcomes among socioeconomic groups within rich and poor countries. Other observers have suggested that neoliberal economic practices may lead to more unequal health outcomes between socioeconomic groups within countries (Hertzman, 2000; Wilkinson, 2000; Kim, 2005).

In sum, our analyses suggest that a more nuanced view of neo-liberalism is required when assessing its relation with population health. Neo-liberalism is not a single entity - different policies traditionally included under that umbrella may have different effects on a country's economic growth (Ayal and Karras, 1998; Carlsson and Lundstrom, 2002) and thus health. Indeed two domains, access to sound money and protection of property rights, appear to promote better health outcomes. Our work also confirms the importance of conducting stratified analyses to understand the differential effects of neo-liberalism on countries at different levels of development. Further work that evaluates the differential contribution of specific economic policies to health is required to better understand these complex associations. Future research should also evaluate the impact of these policies on equity in health outcomes within countries.

\section{Acknowledgements}

The authors would like to thank Dr George Kaplan for helpful comments on an earlier version of this manuscript.

\section{References}

Akhter, S. H. (2004), 'Is globalization what it's cracked up to be? Economic freedom, corruption, and human development', Journal of World Business, 39(3): 283-295.

Ayal, E. B. and G. Karras (1998), 'Components of economic freedom and growth: an empirical study', Journal of Developing Areas, 32(3): 327-338.

Beckfield, J. (2004), 'Does income inequality harm health? New cross-national evidence', Journal of Health and Social Behavior, 45(3): 231-248.

Benzeval, M. and K. Judge (2001), 'Income and health: the time dimension', Social Science and Medicine, 52(9): 1371-1390.

Birdsall, N. (1998), 'Life is unfair: inequality in the world', Foreign Policy, 111: 76-93. 
Blomstrom, M. and A. Kokko (1997), 'The Impact of Foreign Investment on Host Countries: A Review of the Empirical Evidence', World Bank Policy Research Working Paper No. 1745.

Breman, A. and C. Shelton (2007), 'Structural Adjustment Programs and Health'. in I. Kawachi and S. P. Wamala (eds), Globalization and Health, New York: Oxford University Press.

Carlsson, F. and S. Lundstrom (2002), 'Economic freedom and growth: decomposing the effects', Public Choice, 112(3-4): 335-344.

Center for International Development and Conflict Management (2005), Polity IV Project, available at http://www.cidcm.umd.edu/inscr/polity/polreg.htm [4 November 2005].

Chung, H. and C. Muntaner (2007), 'Welfare state matters: a typological multilevel analysis of wealthy countries', Health Policy, 80(2): 328-339.

Clark, G. L., L. McDowell, E. Caerlewy-Smith and K. Strauss (2005), 'After the welfare states: financial welfare and the social sciences', Environment and Planning A, 37(3): $383-384$.

Coburn, D. (2000), 'Income inequality, social cohesion and the health status of populations: the role of neo-liberalism', Social Science and Medicine, 51(1): 135-146.

Coburn, D. (2004), 'Beyond the income inequality hypothesis: class, neo-liberalism, and health inequalities', Social Science and Medicine, 58(1): 41-56.

Cole, J. H. (2003), 'The contribution of economic freedom to world economic growth, 1980-99', Cato Journal, 23(2): 189-199.

Cornia, G. A. (2003), 'The Impact of Liberalization and Globalization on Income Inequality in Developing and Transitional Economies', CESifo Working Paper No. 843.

Cupples, J. (2005), 'Love and money in an age of neoliberalism: gender, work, and single motherhood in postrevolutionary Nicaragua', Environment and Planning A, 37(2): $305-322$.

El-Ghannam, A. R. (2003), 'The global problems of child malnutrition and mortality in different world regions', Journal of Health and Social Policy, 16(4): 1-26.

Esposto, A. G. and P. A. Zaleski (1999), 'Economic freedom and the quality of life: an empirical analysis', Constitutional Political Economy, 10(2): 185-197.

Flegg, A. T. (1982), 'Inequality of income, illiteracy and medical care as determinants of infant mortality in underdeveloped countries', Population Studies, 36(3): 441-458.

Franco, A., C. Alvarez-Dardet and M. T. Ruiz (2004), 'Effect of democracy on health: ecological study', British Medical Journal (Clinical Research Edition), 329(7480): $1421-1423$.

Friedman, M. (1962), Capitalism and Freedom, Chicago, IL: University of Chicago Press.

Gerring, J. and S. C. Thacker (2005), 'Do neoliberal policies deter political corruption?', International Organization, 59(1): 233-254.

Gerring, J. and S. C. Thacker (2008), 'Do neoliberal economic policies kill or save lives?', Business and Politics, 10(3): Article 3.

Graeff, P. and G. Mehlkop (2003), 'The impact of economic freedom on corruption: different patterns for rich and poor countries', European Journal of Political Economy, 19(3): 605-620.

Gravelle, H., J. Wildman and M. Sutton (2002), 'Income, income inequality and health: what can we learn from aggregate data?', Social Science and Medicine, 54(4): $577-589$.

Grosse, R. N. and C. Auffrey (1989), 'Literacy and health status in developing countries', Annual Review of Public Health, 10: 281-297. 
Grubel, H. G. (1998), 'Economic freedom and human welfare: some empirical findings', Cato Journal, 18(2): 287-304.

Gwartney, J. and R. Lawson (2005), Economic Freedom of the World: 2005 Annual Report, Vancouver, BC: The Fraser Institute.

Gwartney, J. D., R. A. Lawson and R. G. Holcombe (1999), 'Economic freedom and the environment for economic growth', Journal of Institutional and Theoretical Economics, 155(4): 643-663.

Hales, S., P. Howden-Chapman, C. Salmond, A. Woodward and J. Mackenbach (1999), 'National infant mortality rates in relation to gross national product and distribution of income', Lancet, 354(9195): 2047.

Hanke, S. H. and S. J. K. Walters (1997), 'Economic freedom, prosperity, and equality: a survey', Cato Journal, 17(2): 117-146.

Hertzman, C. (2000), 'Social change, market forces and health', Social Science and Medicine, 51(7): 1007-1008; discussion 1009-1010.

Huber, E. and R. Solt (2004), 'Successes and failures of neoliberalism', Latin American Research Review, 39(3): 150-164.

Inglehart, R. (2004), European and World Values Surveys Four-wave Integrated Data File, 1981-2004, available at http://www.icpsr.umich.edu [6 December 2005].

Judge, K. (1995), 'Income distribution and life expectancy: a critical appraisal', British Medical Journal (Clinical Research Edition), 311(7015): 1282-1285; discussion 1285-1287.

Kawachi, I., B. P. Kennedy, K. Lochner and D. Prothrow-Stith (1997), 'Social capital, income inequality, and mortality', American Journal of Public Health, 87(9): 1491-1498.

Kennelly, B., E. O'Shea and E. Garvey (2003), 'Social capital, life expectancy and mortality: a cross-national examination', Social Science and Medicine, 56(12): 2367-2377.

Kenworthy, L. (1999), 'Do social-welfare policies reduce poverty? A cross-national assessment', Social Forces, 77(3): 1119-1139.

Kim, C. Y. (2005), 'The Korean economic crisis and coping strategies in the health sector: pro-welfarism or neoliberalism?', International Journal of Health Services, 35(3): 561-578.

Korpi, W. and J. Palme (1998), 'The paradox of redistribution and strategies of equality: welfare state institutions, inequality and poverty in the Western countries', American Sociological Review, 63(5): 661-687.

Kreuger, A. O. (1998), 'Why trade liberalization is good for growth', Economic Journal, 108(450): 1513-1522.

Kunitz, S. J. and I. Pesis-Katz (2005), 'Mortality of white Americans, African Americans, and Canadians: the causes and consequences for health of welfare state institutions and policies', The Milbank Quarterly, 83(1): 5-39.

Labao, L. and G. Hooks (2003), 'Public employment, welfare transfers, and economic wellbeing across local populations: does a lean and mean government benefit the masses?', Social Forces, 82(2): 519-556.

Labra, M. E. (2002), 'Neoliberal reinvention of inequality in Chile: the case of the health sector', Cadernos De Saude Publica, 18(4): 1041-1052.

Lindstrom, C. and M. Lindstrom (2006), “"Social capital,” GNP per capita, relative income, and health: an ecological study of 23 countries', International Journal of Health Services, 36(4): 679-696. 
Lynch, J. (2000), 'Income inequality and health: expanding the debate', Social Science and Medicine, 51(7): 1001-1005; discussion 1009-1010.

Macinko, J., F. C. Guanais, M. de Fatima and M. de Souza (2006), 'Evaluation of the impact of the Family Health Program on infant mortality in Brazil, 1990-2002', Journal of Epidemiology and Community Health, 60(1): 13-19.

Martyn, C. (2004), 'Politics as a determinant of health', British Medical Journal (Clinical Research Edition), 329(7480): 1423-1424.

Mehrtens, F. J. (2004), 'Laissez-faire vs. regulated capitalism: a cross-national analysis of social costs', Sociological Spectrum, 24(3): 341-368.

Mellor, J. M. and J. Milyo (2001), 'Reexamining the evidence of an ecological association between income inequality and health', Journal of Health Politics, Policy and Law, 26(3): 487-522.

Messick, R. E. (ed.) (1996), World Survey of Economic Freedom, 1995-1996, New Brunswick, NJ: Freedom House and Transaction Publishers.

Mogford, L. (2004), 'Structural determinants of child mortality in sub-Saharan Africa: a cross-national study of economic and social influences from 1970 to 1997', Social Biology, 51(3-4): 94-120.

Moore, S., A. C. Teixeira and A. Shiell (2006), 'The health of nations in a global context: trade, global stratification, and infant mortality rates', Social Science and Medicine, 63(1): 165-178.

Morgens, H. J. (1976), 'A third century look at the balance between government and business', Nation's Business, 64(10): 38-40.

Muntaner, C. and J. Lynch (1999), 'Income inequality, social cohesion, and class relations: a critique of Wilkinson's neo-Durkheimian research program', International Journal of Health Services, 29(1): 59-81.

Murray, C. J. and A. D. Lopez (1997), 'Mortality by cause for eight regions of the world: global burden of disease study', Lancet, 349(9061): 1269-1276.

Navarro, V., C. Muntaner, C. Borrell, J. Benach, A. Quiroga, M. Rodriguez-Sanz, N. Verges and M. I. Pasarin (2006), 'Politics and health outcomes', Lancet, 368(9540): 1033-1037.

Nettleson, S. and R. Burrows (1998), 'Mortgage debt, insecure home ownership and health: an exploratory analysis', Sociology of Health and Illness, 20(5): 731-753.

O'Driscoll, G. P. Jr, K. R. Holmes and M. Kirkpatrick (2001), 2001 Index of Economic Freedom, Washington, DC: Heritage Foundation.

Pampel, F. C. Jr and V. K. Pillai (1986), 'Patterns and determinants of infant mortality in developed nations, 1950-1975', Demography, 23(4): 525-542.

Price, D., A. M. Pollock and J. Shaoul (1999), 'How the World Trade Organisation is shaping domestic policies in health care', Lancet, 354(9193): 1889-1892.

Reinhardt, U. E., P. S. Hussey and G. F. Anderson (2002), 'Cross-national comparisons of health systems using OECD data, 1999', Health Affairs, 21(3): 169-181.

Reuveny, R. and Q. Li (2003), 'Economic openness, democracy, and income inequality: an empirical analysis', Comparative Political Studies, 36(5): 575-601.

Ricardo, D. (1996), Principles of Political Economy and Taxation, Amherst, NY: Prometheus Books.

Rodgers, G. B. (1979), 'Income and inequality as determinants of mortality: an international cross-section analysis', Population Studies, 33(3): 343-351.

Ross, C. E. and J. Mirowsky (1995), 'Does employment affect health?', Journal of Health and Social Behavior, 36(3): 230-243. 
Rutstein, S. O. (2000), 'Factors associated with trends in infant and child mortality in developing countries during the 1990s', Bulletin of the World Health Organization, 78(10): 1256-1270.

Schell, C. O., M. Reilly, H. Rosling, S. Peterson and A. M. Ekstrom (2007), 'Socioeconomic determinants of infant mortality: a worldwide study of 152 low-, middle-, and highincome countries', Scandinavian Journal of Public Health, 35(3): 288-297.

Shandra, J. M., J. Nobles, B. London and J. B. Williamson (2004), 'Dependency, democracy, and infant mortality: a quantitative, cross-national analysis of less developed countries', Social Science and Medicine, 59(2): 321-333.

Shen, C. E. and J. B. Williamson (2001), 'Accounting for cross-national differences in infant mortality decline (1965-1991) among less developed countries: effects of women's status, economic dependency, and state strength', Social Indicators Research, 53(3): 257-288.

Shleifer, A. (1998), 'State versus private ownership', Journal of Economic Perspectives, 12(4): 133-150.

Smith, A. (1991), Inquiry into the Nature and Causes of the Wealth of Nations, Amherst, NY: Prometheus Books.

Tarlov, A. R. (2000), 'Coburn's thesis: plausible, but we need more evidence and better measures', Social Science and Medicine, 51(7): 993-995; discussion 1009-1010.

United Nations Development Programme (UNDP) (1995), Human Development Report 1995. Gender and Human Development, New York, NY: Oxford University Press.

United Nations Development Programme (UNDP) (1999), Human Development Report 1999. Globalization with a Human Face, New York, NY: Oxford University Press.

United Nations Development Programme (UNDP) (2000), Human Development Report 2000. Human Rights and Human Development, New York, NY: Oxford University Press.

United Nations Development Programme (UNDP) (2001), Human Development Report 2001. Making New Technologies Work for Human Development, New York, NY: Oxford University Press.

United Nations Development Programme (UNDP) (2006), Human Development Report 2006. Beyond Scarcity: Power, Poverty, and the Global Water Crisis, New York, NY: Palgrave Macmillan.

United Nations University, World Institute for Development Economics Research (2005), World Income Inequality Database, version 2a, available at http://www.wider.unu.edu/ wiid/wiid.htm [3 May 2006].

Wennemo, I. (1993), 'Infant mortality, public policy and inequality - a comparison of 18 industrialised countries, 1950-85', Sociology of Health and Illness, 15(4): 429-446.

Wilkinson, R. G. (1992), 'National mortality rates: the impact of inequality?', American Journal of Public Health, 82(8): 1082-1084.

Wilkinson, R. G. (2000), 'Deeper than "neoliberalism". A reply to David Coburn', Social Science and Medicine, 51(7): 997-1000; discussion 1009-1010.

World Bank (2005), World Development Indicators Database, available at http://devdata. worldbank.org/data-query [14 October 2005].

World Bank (2007), Members, available at http://go.worldbank.org/Y33OQYNE90 [19 October 2007].

Wu, X. and J. M. Perloff (2006), 'Effects of government policies on urban and rural income inequality', Review of Income and Wealth, 52(2): 213-225. 
Neo-liberal economic practices and population health 27

Appendix. Countries included in analyses $(N=119 ; 464 \text { country intervals })^{a}$

\begin{tabular}{|c|c|c|c|c|c|c|c|c|}
\hline \multirow[b]{2}{*}{ Country } & \multicolumn{5}{|c|}{ Data availability by time interval } & \multirow{2}{*}{$\begin{array}{c}\text { Low } \\
\text { income }^{b}\end{array}$} & \multirow{2}{*}{$\begin{array}{c}\text { High } \\
\text { income }^{b}\end{array}$} & \multirow{2}{*}{$\begin{array}{l}\text { Highest } \\
\text { income }\end{array}$} \\
\hline & 1980-1984 & 1985-1989 & 1990-1994 & 1995-1999 & 2000-2004 & & & \\
\hline Albania & & & $\mathrm{X}$ & $\mathrm{X}$ & $\mathrm{X}$ & $\mathrm{X}$ & & \\
\hline Algeria & $\mathrm{X}$ & & $\mathrm{X}$ & $\mathrm{X}$ & $\mathrm{X}$ & $\mathrm{X}$ & & \\
\hline Argentina & $\mathrm{X}$ & & $\mathrm{X}$ & $\mathrm{X}$ & $\mathrm{X}$ & & $\mathrm{X}$ & \\
\hline Australia & $\mathrm{X}$ & $\mathrm{X}$ & $\mathrm{X}$ & $\mathrm{X}$ & $\mathrm{X}$ & & $\mathrm{X}$ & $\mathrm{X}$ \\
\hline Austria & $\mathrm{X}$ & $\mathrm{X}$ & $\mathrm{X}$ & $\mathrm{X}$ & $\mathrm{X}$ & & $\mathrm{X}$ & $\mathrm{X}$ \\
\hline Bahamas & $\mathrm{X}$ & & $\mathrm{X}$ & $\mathrm{X}$ & $\mathrm{X}$ & & $\mathrm{X}$ & $\mathrm{X}$ \\
\hline Bahrain & $\mathrm{X}$ & & $\mathrm{X}$ & $\mathrm{X}$ & $\mathrm{X}$ & & $\mathrm{X}$ & $\mathrm{X}$ \\
\hline Bangladesh & $\mathrm{X}$ & & $\mathrm{X}$ & $\mathrm{X}$ & $\mathrm{X}$ & $\mathrm{X}$ & & \\
\hline Belgium & $\mathrm{X}$ & & $\mathrm{X}$ & $\mathrm{X}$ & $\mathrm{X}$ & & $\mathrm{X}$ & $\mathrm{X}$ \\
\hline Belize & $\mathrm{X}$ & & $\mathrm{X}$ & $\mathrm{X}$ & $\mathrm{X}$ & & $\mathrm{X}$ & \\
\hline Benin & $\mathrm{X}$ & & $\mathrm{X}$ & $\mathrm{X}$ & $\mathrm{X}$ & $\mathrm{X}$ & & \\
\hline Bolivia & $\mathrm{X}$ & & $\mathrm{X}$ & $\mathrm{X}$ & $\mathrm{X}$ & $\mathrm{X}$ & & \\
\hline Botswana & $\mathrm{X}$ & & $\mathrm{X}$ & $\mathrm{X}$ & $\mathrm{X}$ & & $\mathrm{X}$ & \\
\hline Brazil & $\mathrm{X}$ & & $\mathrm{X}$ & $\mathrm{X}$ & $\mathrm{X}$ & $\mathrm{X}$ & & \\
\hline Bulgaria & & $\mathrm{X}$ & $\mathrm{X}$ & $\mathrm{X}$ & $\mathrm{X}$ & $\mathrm{X}$ & & \\
\hline Burundi & $\mathrm{X}$ & & $\mathrm{X}$ & $\mathrm{X}$ & $\mathrm{X}$ & $\mathrm{X}$ & & \\
\hline Cameroon & $\mathrm{X}$ & & $\mathrm{X}$ & $\mathrm{X}$ & $\mathrm{X}$ & $\mathrm{X}$ & & \\
\hline Canada & $\mathrm{X}$ & $\mathrm{X}$ & $\mathrm{X}$ & $\mathrm{X}$ & $\mathrm{X}$ & & $\mathrm{X}$ & $\mathrm{X}$ \\
\hline Central African Republic & & & $\mathrm{X}$ & $\mathrm{X}$ & $\mathrm{X}$ & $\mathrm{X}$ & & \\
\hline Chad & & & $\mathrm{X}$ & $\mathrm{X}$ & $\mathrm{X}$ & $\mathrm{X}$ & & \\
\hline Chile & $\mathrm{X}$ & & $\mathrm{X}$ & $\mathrm{X}$ & $\mathrm{X}$ & & $\mathrm{X}$ & \\
\hline China & $\mathrm{X}$ & & $\mathrm{X}$ & $\mathrm{X}$ & $\mathrm{X}$ & $\mathrm{X}$ & & \\
\hline Colombia & $\mathrm{X}$ & & $\mathrm{X}$ & $\mathrm{X}$ & $\mathrm{X}$ & $\mathrm{X}$ & & \\
\hline $\begin{array}{l}\text { Congo, Democratic } \\
\text { Republic of }\end{array}$ & $\mathrm{X}$ & & $\mathrm{X}$ & $\mathrm{X}$ & $\mathrm{X}$ & $\mathrm{X}$ & & \\
\hline Congo, Republic of & $\mathrm{X}$ & & $\mathrm{X}$ & $\mathrm{X}$ & $\mathrm{X}$ & $\mathrm{X}$ & & \\
\hline Costa Rica & $\mathrm{X}$ & & $\mathrm{X}$ & $\mathrm{X}$ & $\mathrm{X}$ & & $\mathrm{X}$ & \\
\hline Cote d'Ivoire & $\mathrm{X}$ & & $\mathrm{X}$ & $\mathrm{X}$ & $\mathrm{X}$ & $\mathrm{X}$ & & \\
\hline Croatia & & & & $\mathrm{X}$ & $\mathrm{X}$ & & $\mathrm{X}$ & \\
\hline Cyprus & $\mathrm{X}$ & & $\mathrm{X}$ & $\mathrm{X}$ & $\mathrm{X}$ & & $\mathrm{X}$ & $\mathrm{X}$ \\
\hline Czech Republic & & & & $\mathrm{X}$ & $\mathrm{X}$ & & $\mathrm{X}$ & \\
\hline Denmark & $\mathrm{X}$ & $\mathrm{X}$ & $\mathrm{X}$ & $\mathrm{X}$ & $\mathrm{X}$ & & $\mathrm{X}$ & $\mathrm{X}$ \\
\hline Dominican Republic & $\mathrm{X}$ & & $\mathrm{X}$ & $\mathrm{X}$ & $\mathrm{X}$ & $\mathrm{X}$ & & \\
\hline Ecuador & $\mathrm{X}$ & & $\mathrm{X}$ & $\mathrm{X}$ & $\mathrm{X}$ & $\mathrm{X}$ & & \\
\hline Egypt, Arab Republic of & $\mathrm{X}$ & & $\mathrm{X}$ & $\mathrm{X}$ & $\mathrm{X}$ & $\mathrm{X}$ & & \\
\hline El Salvador & $\mathrm{X}$ & & $\mathrm{X}$ & $\mathrm{X}$ & $\mathrm{X}$ & $\mathrm{X}$ & & \\
\hline Estonia & & & & $\mathrm{X}$ & $\mathrm{X}$ & & $\mathrm{X}$ & \\
\hline Fiji & $\mathrm{X}$ & & $\mathrm{X}$ & $\mathrm{X}$ & $\mathrm{X}$ & $\mathrm{X}$ & & \\
\hline Finland & $\mathrm{X}$ & $\mathrm{X}$ & $\mathrm{X}$ & $\mathrm{X}$ & $\mathrm{X}$ & & $\mathrm{X}$ & $\mathrm{X}$ \\
\hline France & $\mathrm{X}$ & $\mathrm{X}$ & $\mathrm{X}$ & $\mathrm{X}$ & $\mathrm{X}$ & & $\mathrm{X}$ & $\mathrm{X}$ \\
\hline Gabon & $\mathrm{X}$ & & $\mathrm{X}$ & $\mathrm{X}$ & $\mathrm{X}$ & & $\mathrm{X}$ & \\
\hline Germany & $\mathrm{X}$ & $\mathrm{X}$ & $\mathrm{X}$ & $\mathrm{X}$ & $\mathrm{X}$ & & $\mathrm{X}$ & $\mathrm{X}$ \\
\hline Ghana & $\mathrm{X}$ & & $\mathrm{X}$ & $\mathrm{X}$ & $\mathrm{X}$ & $\mathrm{X}$ & & \\
\hline Greece & $\mathrm{X}$ & & $\mathrm{X}$ & $\mathrm{X}$ & $\mathrm{X}$ & & $\mathrm{X}$ & $\mathrm{X}$ \\
\hline Guatemala & $\mathrm{X}$ & & $\mathrm{X}$ & $\mathrm{X}$ & $\mathrm{X}$ & $\mathrm{X}$ & & \\
\hline Guinea-Bissau & & & $\mathrm{X}$ & $\mathrm{X}$ & $\mathrm{X}$ & $\mathrm{X}$ & & \\
\hline Guyana & & & & $\mathrm{X}$ & $\mathrm{X}$ & $\mathrm{X}$ & & \\
\hline Haiti & $\mathrm{x}$ & & $\mathrm{X}$ & $\mathrm{X}$ & $\mathrm{X}$ & $\mathrm{X}$ & & \\
\hline Honduras & $\mathrm{X}$ & & $\mathrm{X}$ & $\mathrm{X}$ & $\mathrm{X}$ & $\mathrm{X}$ & & \\
\hline Hungary & $\mathrm{X}$ & $\mathrm{X}$ & $\mathrm{X}$ & $\mathrm{X}$ & $\mathrm{X}$ & & $\mathrm{X}$ & \\
\hline Iceland & $\mathrm{X}$ & & $\mathrm{X}$ & $\mathrm{X}$ & $\mathrm{X}$ & & $\mathrm{X}$ & $\mathrm{X}$ \\
\hline
\end{tabular}


Appendix. (Continued)

\begin{tabular}{|c|c|c|c|c|c|c|c|c|}
\hline \multirow[b]{2}{*}{ Country } & \multicolumn{5}{|c|}{ Data availability by time interval } & \multirow{2}{*}{$\begin{array}{c}\text { Low } \\
\text { income }^{b}\end{array}$} & \multirow{2}{*}{$\begin{array}{c}\text { High } \\
\text { income }^{b}\end{array}$} & \multirow{2}{*}{$\begin{array}{l}\text { Highest } \\
\text { income }^{c}\end{array}$} \\
\hline & 1980-1984 & $1985-1989$ & 1990-1994 & 1995-1999 & 2000-2004 & & & \\
\hline India & $\mathrm{X}$ & & $\mathrm{X}$ & $\mathrm{X}$ & $\mathrm{X}$ & $\mathrm{X}$ & & \\
\hline Indonesia & $\mathrm{X}$ & & $\mathrm{X}$ & $\mathrm{X}$ & $\mathrm{X}$ & $\mathrm{X}$ & & \\
\hline Iran, Islamic Republic of & $\mathrm{X}$ & & $\mathrm{X}$ & $\mathrm{X}$ & $\mathrm{X}$ & $\mathrm{X}$ & & \\
\hline Ireland & $\mathrm{X}$ & $\mathrm{X}$ & $\mathrm{X}$ & $\mathrm{X}$ & $\mathrm{X}$ & & $\mathrm{X}$ & $\mathrm{X}$ \\
\hline Israel & $\mathrm{X}$ & & $\mathrm{X}$ & $\mathrm{X}$ & $\mathrm{X}$ & & $\mathrm{X}$ & $\mathrm{X}$ \\
\hline Italy & $\mathrm{X}$ & $\mathrm{X}$ & $\mathrm{X}$ & $\mathrm{X}$ & $\mathrm{X}$ & & $\mathrm{X}$ & $\mathrm{X}$ \\
\hline Jamaica & $\mathrm{X}$ & & $\mathrm{X}$ & $\mathrm{X}$ & $\mathrm{X}$ & & $\mathrm{X}$ & \\
\hline Japan & $\mathrm{X}$ & $\mathrm{X}$ & $\mathrm{X}$ & $\mathrm{X}$ & $\mathrm{X}$ & & $\mathrm{X}$ & $\mathrm{X}$ \\
\hline Jordan & $\mathrm{X}$ & & $\mathrm{X}$ & $\mathrm{X}$ & $\mathrm{X}$ & $\mathrm{X}$ & & \\
\hline Kenya & $\mathrm{X}$ & & $\mathrm{X}$ & $\mathrm{X}$ & $\mathrm{X}$ & $\mathrm{X}$ & & \\
\hline Korea, Republic of & $\mathrm{X}$ & & $\mathrm{X}$ & $\mathrm{X}$ & $\mathrm{X}$ & & $\mathrm{X}$ & $\mathrm{X}$ \\
\hline Kuwait & $\mathrm{X}$ & & & $\mathrm{X}$ & $\mathrm{X}$ & & $\mathrm{X}$ & $\mathrm{X}$ \\
\hline Latvia & & & & $\mathrm{X}$ & $\mathrm{X}$ & & $\mathrm{X}$ & \\
\hline Lithuania & & & & $\mathrm{X}$ & $\mathrm{X}$ & & $\mathrm{X}$ & \\
\hline Luxembourg & $\mathrm{X}$ & $\mathrm{X}$ & $\mathrm{X}$ & $\mathrm{X}$ & $\mathrm{X}$ & & $\mathrm{X}$ & $\mathrm{X}$ \\
\hline Madagascar & $\mathrm{X}$ & & $\mathrm{X}$ & $\mathrm{X}$ & $\mathrm{X}$ & $\mathrm{X}$ & & \\
\hline Malawi & $\mathrm{X}$ & & $\mathrm{X}$ & $\mathrm{X}$ & $\mathrm{X}$ & $\mathrm{X}$ & & \\
\hline Malaysia & $\mathrm{X}$ & & $\mathrm{X}$ & $\mathrm{X}$ & $\mathrm{X}$ & & $\mathrm{X}$ & \\
\hline Mali & $\mathrm{X}$ & & $\mathrm{X}$ & $\mathrm{X}$ & $\mathrm{X}$ & $\mathrm{X}$ & & \\
\hline Malta & $\mathrm{X}$ & & $\mathrm{X}$ & $\mathrm{X}$ & $\mathrm{X}$ & & $\mathrm{X}$ & $\mathrm{X}$ \\
\hline Mauritius & $\mathrm{X}$ & & $\mathrm{X}$ & $\mathrm{X}$ & $\mathrm{X}$ & & $\mathrm{X}$ & \\
\hline Mexico & $\mathrm{X}$ & & $\mathrm{X}$ & $\mathrm{X}$ & $\mathrm{X}$ & & $\mathrm{X}$ & \\
\hline Morocco & $\mathrm{X}$ & & $\mathrm{X}$ & $\mathrm{X}$ & $\mathrm{X}$ & $\mathrm{X}$ & & \\
\hline Namibia & & & $\mathrm{X}$ & $\mathrm{X}$ & $\mathrm{X}$ & $\mathrm{X}$ & & \\
\hline Nepal & $\mathrm{X}$ & & $\mathrm{X}$ & $\mathrm{X}$ & $\mathrm{X}$ & $\mathrm{X}$ & & \\
\hline Netherlands & $\mathrm{X}$ & $\mathrm{X}$ & $\mathrm{X}$ & $\mathrm{X}$ & $\mathrm{X}$ & & $\mathrm{X}$ & $\mathrm{X}$ \\
\hline New Zealand & $\mathrm{X}$ & & $\mathrm{X}$ & $\mathrm{X}$ & $\mathrm{X}$ & & $\mathrm{X}$ & $\mathrm{X}$ \\
\hline Nicaragua & $\mathrm{X}$ & & $\mathrm{X}$ & $\mathrm{X}$ & $\mathrm{X}$ & $\mathrm{X}$ & & \\
\hline Niger & $\mathrm{X}$ & & $\mathrm{X}$ & $\mathrm{X}$ & $\mathrm{X}$ & $\mathrm{X}$ & & \\
\hline Nigeria & $\mathrm{X}$ & & $\mathrm{X}$ & $\mathrm{X}$ & $\mathrm{X}$ & $\mathrm{X}$ & & \\
\hline Norway & $\mathrm{X}$ & $\mathrm{X}$ & $\mathrm{X}$ & $\mathrm{X}$ & $\mathrm{X}$ & & $\mathrm{X}$ & $\mathrm{X}$ \\
\hline Oman & & & $\mathrm{X}$ & $\mathrm{X}$ & $\mathrm{X}$ & & $\mathrm{X}$ & \\
\hline Pakistan & $\mathrm{X}$ & & $\mathrm{X}$ & $\mathrm{X}$ & $\mathrm{X}$ & $\mathrm{X}$ & & \\
\hline Panama & $\mathrm{X}$ & & $\mathrm{X}$ & $\mathrm{X}$ & $\mathrm{X}$ & & $\mathrm{X}$ & \\
\hline Papua New Guinea & & & $\mathrm{X}$ & $\mathrm{X}$ & $\mathrm{X}$ & $\mathrm{X}$ & & \\
\hline Paraguay & $\mathrm{X}$ & & $\mathrm{X}$ & $\mathrm{X}$ & $\mathrm{X}$ & $\mathrm{X}$ & & \\
\hline Peru & $\mathrm{X}$ & & $\mathrm{X}$ & $\mathrm{X}$ & $\mathrm{X}$ & $\mathrm{X}$ & & \\
\hline Philippines & $\mathrm{X}$ & & $\mathrm{X}$ & $\mathrm{X}$ & $\mathrm{X}$ & $\mathrm{X}$ & & \\
\hline Poland & & & $\mathrm{X}$ & $\mathrm{X}$ & $\mathrm{X}$ & & $\mathrm{X}$ & \\
\hline Portugal & $\mathrm{X}$ & & $\mathrm{X}$ & $\mathrm{X}$ & $\mathrm{X}$ & & $\mathrm{X}$ & $\mathrm{X}$ \\
\hline Romania & & & $\mathrm{X}$ & $\mathrm{X}$ & $\mathrm{X}$ & $\mathrm{X}$ & & \\
\hline Russian Federation & & & & $\mathrm{X}$ & $\mathrm{X}$ & & & \\
\hline Rwanda & & & $\mathrm{X}$ & $\mathrm{X}$ & $\mathrm{X}$ & $\mathrm{X}$ & & \\
\hline Senegal & $\mathrm{X}$ & & $\mathrm{X}$ & $\mathrm{X}$ & $\mathrm{X}$ & $\mathrm{X}$ & & \\
\hline Sierra Leone & $\mathrm{X}$ & & $\mathrm{X}$ & $\mathrm{X}$ & $\mathrm{X}$ & $\mathrm{X}$ & & \\
\hline Singapore & $\mathrm{X}$ & $\mathrm{X}$ & $\mathrm{X}$ & $\mathrm{X}$ & $\mathrm{X}$ & & $\mathrm{X}$ & $\mathrm{X}$ \\
\hline Slovakia & & & & $\mathrm{X}$ & $\mathrm{X}$ & & & \\
\hline Slovenia & & & & $\mathrm{X}$ & $\mathrm{X}$ & & $\mathrm{X}$ & $\mathrm{X}$ \\
\hline South Africa & $\mathrm{X}$ & $\mathrm{X}$ & $\mathrm{X}$ & $\mathrm{X}$ & $\mathrm{X}$ & $\mathrm{X}$ & & \\
\hline Spain & $\mathrm{X}$ & & $\mathrm{X}$ & $\mathrm{X}$ & $\mathrm{X}$ & & $\mathrm{X}$ & $\mathrm{X}$ \\
\hline Sri Lanka & $\mathrm{X}$ & & $\mathrm{X}$ & $\mathrm{X}$ & $\mathrm{X}$ & $\mathrm{X}$ & & \\
\hline Sweden & $\mathrm{X}$ & $\mathrm{X}$ & $\mathrm{X}$ & $\mathrm{X}$ & $\mathrm{X}$ & & $\mathrm{x}$ & $\mathrm{X}$ \\
\hline
\end{tabular}


Appendix. (Continued)

\begin{tabular}{|c|c|c|c|c|c|c|c|c|}
\hline \multirow[b]{2}{*}{ Country } & \multicolumn{5}{|c|}{ Data availability by time interval } & \multirow{2}{*}{$\begin{array}{c}\text { Low } \\
\text { income }^{b}\end{array}$} & \multirow{2}{*}{$\begin{array}{c}\text { High } \\
\text { income }^{b}\end{array}$} & \multirow{2}{*}{$\begin{array}{l}\text { Highest } \\
\text { income }^{c}\end{array}$} \\
\hline & 1980-1984 & 1985-1989 & 1990-1994 & 1995-1999 & 2000-2004 & & & \\
\hline Switzerland & $\mathrm{X}$ & $\mathrm{X}$ & $\mathrm{X}$ & $\mathrm{X}$ & $\mathrm{X}$ & & $\mathrm{X}$ & $\mathrm{X}$ \\
\hline Syrian Arab Republic & $\mathrm{X}$ & & $\mathrm{X}$ & $\mathrm{X}$ & $\mathrm{X}$ & $\mathrm{X}$ & & \\
\hline Tanzania & & & $\mathrm{X}$ & $\mathrm{X}$ & $\mathrm{x}$ & $\mathrm{X}$ & & \\
\hline Thailand & $\mathrm{X}$ & & $\mathrm{X}$ & $\mathrm{X}$ & $\mathrm{X}$ & $\mathrm{X}$ & & \\
\hline Togo & $\mathrm{X}$ & & $\mathrm{X}$ & $\mathrm{X}$ & $\mathrm{X}$ & $\mathrm{X}$ & & \\
\hline Trinidad and Tobago & $\mathrm{X}$ & & $\mathrm{X}$ & $\mathrm{X}$ & $\mathrm{X}$ & & $\mathrm{X}$ & \\
\hline Tunisia & $\mathrm{X}$ & & $\mathrm{X}$ & $\mathrm{x}$ & $\mathrm{X}$ & $\mathrm{X}$ & & \\
\hline Turkey & $\mathrm{X}$ & & $\mathrm{X}$ & $\mathrm{X}$ & $\mathrm{X}$ & $\mathrm{X}$ & & \\
\hline Uganda & $\mathrm{X}$ & & $\mathrm{X}$ & $\mathrm{X}$ & $\mathrm{X}$ & $\mathrm{X}$ & & \\
\hline Ukraine & & & & $\mathrm{x}$ & $\mathrm{X}$ & $\mathrm{X}$ & & \\
\hline United Arab Emirates & $\mathrm{X}$ & & $\mathrm{X}$ & $\mathrm{X}$ & $\mathrm{X}$ & & $\mathrm{X}$ & $\mathrm{X}$ \\
\hline United Kingdom & $\mathrm{X}$ & $\mathrm{X}$ & $\mathrm{X}$ & $\mathrm{X}$ & $\mathrm{X}$ & & $\mathrm{X}$ & $\mathrm{X}$ \\
\hline United States & $\mathrm{X}$ & $\mathrm{X}$ & $\mathrm{X}$ & $\mathrm{X}$ & $\mathrm{X}$ & & $\mathrm{X}$ & $\mathrm{X}$ \\
\hline Uruguay & $\mathrm{X}$ & & $\mathrm{X}$ & $\mathrm{X}$ & $\mathrm{X}$ & & $\mathrm{X}$ & \\
\hline $\begin{array}{l}\text { Venezuela, Republica } \\
\text { Bolivariana de }\end{array}$ & $\mathrm{X}$ & & $\mathrm{X}$ & $\mathrm{X}$ & $\mathrm{X}$ & & $\mathrm{X}$ & \\
\hline Zambia & $\mathrm{X}$ & & $\mathrm{X}$ & $\mathrm{X}$ & $\mathrm{X}$ & $\mathrm{X}$ & & \\
\hline Zimbabwe & $\mathrm{X}$ & & $\mathrm{X}$ & $\mathrm{X}$ & $\mathrm{X}$ & $\mathrm{X}$ & & \\
\hline
\end{tabular}

${ }^{\text {a }}$ Country intervals shaded in gray were also included in models predicting outcomes with adjustment for Gini coefficient, social capital and female literacy ( $N=60$ countries, 107 country intervals).

b"High-income countries" are those classified by the World Bank as "upper middle" or "high" income countries according to 2003 GNI (gross national income) per capita; "low-income countries" are those classified as "lower-middle" or "low" income.

"Highest income" countries are those classified by the World Bank as "high" income countries according to 2003 GNI per capita.

' $\mathrm{X}$ ' indicates the inclusion of an observation in the analysis for a given country in a given time interval. 